\title{
Institutional Risk Preference and Asymmetric Role of Institutional Distance: An Examination on the OFDI of China
}

\author{
Yawei Qi $\mathbb{D}$ and Guangping Rao \\ School of Information Management, Jiangxi University of Finance and Economics, Nanchang 330032, China \\ Correspondence should be addressed to Yawei Qi; qiyawei@jxufe.edu.cn
}

Received 18 May 2021; Revised 10 June 2021; Accepted 16 June 2021; Published 25 June 2021

Academic Editor: Daqing Gong

Copyright (C) 2021 Yawei Qi and Guangping Rao. This is an open access article distributed under the Creative Commons Attribution License, which permits unrestricted use, distribution, and reproduction in any medium, provided the original work is properly cited.

\begin{abstract}
With the implementation of the "Going Out" policy and the "Belt and Road" initiative, Chinese outward foreign direct investment (OFDI) in the countries along the "Belt and Road" increased substantially in the past decade. This paper analyzes the impact of institutional distance on Chinese OFDI and whether Chinese OFDI exhibits institutional risk preferences, using data on Chinese OFDI in 41 countries along the "Belt and Road" for the period from 2003 to 2018. We find that political institutional distance and economic institutional distance are both positively related to China's OFDI scale, while cultural distance has a negative impact on the investment scale. We also find that institutional distance has an asymmetric effect on China's OFDI. In particular, the worse the host country's political environment, the larger the Chinese OFDI, indicating that Chinese OFDI exhibits the political institutional risk preference. On the other hand, Chinese multinational enterprises are more willing to invest in host countries with high economic freedom. Culture institution environment of the host country has a positive but insignificant impact on the Chinese OFDI scale, indicating that Chinese OFDI shows the characteristics of cultural distance proximity.
\end{abstract}

\section{Introduction}

With the continuous development and implementation of the "Going Out" policy, China's outward foreign direct investment (OFDI) has risen rapidly in the past decade. In particular, with the advocacy of the "Belt and Road" initiative, China's OFDI in countries along the "Belt and Road" has drastically increased in recent years. From 2014 to 2016, China's investment in countries along the "Belt and Road" has accumulated more than $\$ 50$ billion. Chinese multinational enterprises (MNEs) have built 56 economic and trade cooperation zones in more than 20 countries, creating nearly $\$ 1.1$ billion in taxes and 180,000 jobs for these countries. In 2017, China's outward foreign direct investment stock was US $\$ 1809.04$ billion, the second highest level in history after the US $\$ 7797.59$ billion reached in the United States (Statistical Bulletin of China's OFDI in 2017). One of the salient features of China's OFDI is that state-owned enterprises, as the main implementer of national policies, were the main subjects of China's OFDI. In 2006, state-owned enterprises accounted for $81 \%$ of the OFDI stock. In recent years, with the diversified development of investment subjects, investment motivation, and investment industries, the proportion of state-owned enterprises in the OFDI stock has been decreasing. But in 2018, the proportion of state-owned enterprises was still as high as $48 \%$ (Statistical Bulletin of China's OFDI in 2019). The dominant role of state-owned enterprises in China's OFDI has not changed.

With the rise of transnational investment, the issue of political risks faced by Chinese enterprises' outward direct investment has attracted wide attention. Ramasamy et al. [1] point out that China's state-owned enterprises prefer to enter countries with high political risks. Yang et al. [2] find that the top 30 destination countries of China's OFDI along "the Belt and Road" can be described as high corruption, high political risk, and imperfect rule of law, including countries such as Kazakhstan, Russia, Indonesia, Burma, Mongolia, Kampuchea, Pakistan, Iran, Venezuela, Zambia, Nigeria, and Laos. Researchers also note that, due to institutional factors such as politics, economy, culture, and 
customs, it is difficult for China to achieve mutual benefits and win-win outcomes with the host countries via OFDI. According to the US Enterprise Research Institute and the Traditional Foundation's China Global Investment Tracking Data, in the past ten years, the amount of overseas investment failed by Chinese enterprises exceeded US $\$ 250$ billion [3].

As the largest developing country, China's unique institutional characteristics in the transition period have become the focus of attention. The political attribute of stateowned enterprises makes China's OFDI have strong institutional preference. In the twenty-first century, under the background of the new international trade and investment rules, the political risks and institutional preferences faced by Chinese state-owned enterprises have undergone structural changes. Using the panel dataset of China's OFDI to 41 countries along the "Belt and Road" from 2003 to 2018, this paper analyzes the influence of the institutional quality of the host country and bilateral institutional distance between China and the host country on the location distribution and investment scale of China's OFDI, which is of great significance for improving the institutional theory of OFDI. China provides an appropriate and unique setting for examining the influence of institutional factors on OFDI. At the same time, institutional characteristics of China's OFDI can be used for reference for the healthy development of OFDI in other developing countries.

Mainstream investment theories stipulate that OFDI should be flowed into host countries with high institutional quality, especially low political risk [4-7]. A good institutional environment is a driver of economic growth, which reduces the distortion of resource allocation and nonproductive consumption in social and economic activities, such as rent-seeking, black market transactions, and corruption, and reduces the transaction costs of multinational enterprises' investment and trade in the host country. For example, Kobrin [8] shows that the host country's political decision-making or events would affect the business environment, impacting investors' operating profits. Lensink [9] finds that the uncertainty of political risk represents a kind of change in economic environment, which undermines the operating profits of multinational enterprises. Jiang and Jiang [10] find that China's OFDI tends to flow into the countries with stricter rule of law and corruption control, and China's OFDI has a positive relationship with the host countries' supervision and government efficiency. Yang et al. [2] illustrate that Chinese MNEs are prone to locate their investments in countries with high institutional quality, less economic development, and more natural resources, which is motivated by higher investment return and access to cheaper resources.

Some prior research shows that Chinese MNEs appear to display a distinctive pattern to institutional risk, referred to as the puzzle of Chinese OFDI institutional risk preference. Buckley et al. [11] analyze the investment behavior of Chinese MNEs and find that China's OFDI is indeed distinctive, particularly regarding political risk. Some researchers study China's OFDI from the institutional environment and investment-oriented perspective of the host country and show a positive relationship between the natural resource endowment of the host country and China's OFDI, while the political institution of the host country is negatively related to Chinese OFDI [12-15]. Deng [16] analyzes the influence of the host country's institutional factors and institutional distance on the location distribution of China's OFDI. The results indicate that the economic and legal institution has a significantly positive impact on the absorption of OFDI spillover effect in developing countries but has no significant impact in developed countries; the institutional distance has a significantly negative impact on the absorption of OFDI spillover effect in host countries. Wang [17] studies China's OFDI from the perspective of economic system and concludes that there is a positive relation between China's OFDI and the host country's economic freedom, commercial freedom, fiscal freedom, and investment freedom, while there is a negative relation between China's OFDI and the host country's trade freedom.

When investing in foreign markets, MNEs must adapt their strategies to satisfy the requirements of local institutions, which may differ from the institutions of their home countries. Thus, institutional distance between home and host countries represents an important factor that influences MNEs' OFDI. Firms perform better in foreign markets similar to their home markets than in markets that are dissimilar, as similarities are easier for firms to manage [18]. Differences between home and host countries in terms of corruption, legal rules, credit market regulations, and legal constraints on recruiting and firing workers reduce bilateral OFDI flows [19]. Pan [20] finds that institutional distance negatively impacts OFDI, while the differences in monetary policy, wage control degree, and trade policy are more influential. In addition, among the institutional quality variables, the degree of market intensity and the degree of private property protection and monetary policy play a major role in explaining OFDI. Yue and Fan [21] show that the bilateral institutional distance is a more important influencing factor than the host country's environmental environment; China's OFDI was prone to flow into a host country, whose institutional environment differs greatly from that of China, and especially the host countries with poor institutional environment. Qi and Zou [22] show that formal institutional quality (the rule of law, economic institution) of the host country is positively related to the amount of China's OFDI, while cultural distance between the host country and China hinders China's OFDI. In addition to institutional similarities, development, geographical, and cultural proximity are important determinants of OFDI [23-25].

The costs of institutional distance may differ for firms from developed than those from developing countries. Firms from developed countries may have more experience and better networks than firms from developing countries, and this can help firms from developed countries better reduce the cost of institutional distance [18]. Some scholars believe that bilateral agreements and overseas Chinese relational networks can mitigate the negative impacts of institutional distance on China's OFDI Hu and Fan [26]. The institutional environments of host countries are different, and thus, the 
institutional preference of a country's OFDI can be different. When investing in countries with weak institutions, firms from countries with weak institutions face lower costs than firms from countries with strong institutions. Prior findings also indicate that institutional distance more strongly influences firms' decisions to invest in developing than in developed economies. Qi and Zou [27] find that the effect of institutional distance is asymmetric. That is, when developing countries invest in host countries with higher institutional quality, they will choose countries with a larger institutional distance; when developing countries invest in host countries with poorer institutional environment than their own, they will choose a country with a closer institutional environment. Zhou et al. [28] study the impact of institutional environment on China's OFDI using Heckman model and find that China's OFDI has institutional proximity to developed host countries and does not have institutional proximity to developing host countries.

The existing literature and opinions can only explain outward foreign investment activities among developed countries and developing countries. Institutional distance well explains the outward foreign investment behavior of emerging economies and transition economies without competitive advantages. Different from western developed countries, the main object of China's OFDI is state-owned enterprises (SOEs). The outward foreign investment behavior of state-owned enterprises is deeply affected by government participation and control. China's institutional characteristics make it the most appropriate and unique setting for examining the influence of institutional factors on OFDI. We reconsider the relationship between institutional quality of the host country and China's OFDI and examine the "China's OFDI risk preference theory" proposed by previous studies. Given that the institutional environment of a country is a complex multidimensional construct, the impacts of institutional environment in different dimensions may differ from its overall effect. Thus, we consider the political institutional environment, the economic institutional environment, and the cultural institutional environment and examine the different impacts of each type of institution environment on China's OFDI.

In contrast with prior studies in this area, this paper focuses on China's OFDI in 41 countries along the "Belt and Road" from 2003 to 2018. Using the two-stage Heckman model with trade gravity, we find that large political distance reduces the willingness of Chinese MNEs to invest abroad, but once investment decision is made, the amount of Chinese OFDI is positively related to political distance. In addition, economic institutional distance has a significantly positive impact on the amount of Chinese OFDI. On the other hand, cultural distance has a significantly negative impact on the volume of Chinese OFDI. We further find that institutional distance has an asymmetric effect on the OFDI. The Chinese OFDI tends to flow into the host countries with a poorer political institutional environment, a better economic environment, and a similar cultural environment. Our results clearly show that Chinese OFDI presents political institutional risk preference and characteristics of cultural distance proximity.
The contributions of this paper to the literature are as follows. First, this paper divides the institutional environment of the host country into the political institutional environment, the economic institutional environment, and the cultural institutional environment and delves deeply into the characteristics of China's OFDI preferences for various aspects of institutional environment. Thus, the analysis of this paper is more comprehensive, more specific, and more practically relevant. Second, this paper constructs a Heckman two-stage model with trade gravitation to analyze the impact of institutional environment of the host country and bilateral institutional distance on China's OFDI. This model allows us to analyze how the host country's institutional environment is related to both the willingness of China's OFDI and the size of OFDI in the country, and our analysis is less subject to sample selection bias. Third, in addition to considering the size of the institutional distance, we also consider the direction of the institutional distance; that is, we analyze whether China's OFDI outflows to the host country, whose institutional quality is better or worse than China's, in order to clarify the puzzle of China's OFDI institutional risk preference and examine the asymmetric effect of institutional distance.

The remainder of this paper is structured as follows: In Section 2, we explore the interrelated theories and propose the related hypothesis; Section 3 takes China's OFDI to 41 countries along the "Belt and Road" from 2003 to 2018 as a sample and builds Heckman model with trade gravity; Section 4 is empirical results, used to analyze the impact of host countries' institutional quality and institutional distance on OFDI decision-making and scale; Section 5 is conclusions and related suggestions.

\section{Hypothesis Development}

North [29] defines institutions as the constraints built by men and designed to organize people's interrelationships. He classifies institutions into formal and informal institutions. Formal institutions include regulations, property rights, the financial system, and contract enforcement, referring to the laws and regulations that obligate people's code of conduct [30], while informal institutions refer to people's customary code of conduct in social interactions, which do not require written laws and regulations, and include levels of social trust [31] and corruption [19]. In this paper, the formal institution is divided into political institution and economic institution, and the informal institution mainly refers to cultural institution environment.

\subsection{The Impacts of the Formal Institutional Distance between} the Host Country and China on Chinese OFDI. Habib and Zurawicki [19] propose the institutional proximity theory and find that the smaller the gap in institution between the source and destination countries, the greater the bilateral foreign direct investment flow, using the data from developed countries. Chinese MNEs are predominantly stateowned enterprises (SOEs), which have the support of the government and do not necessarily act as profit- 
maximizers. In other words, Chinese SOEs have some political purposes and are obliged to fulfill political objectives by providing support for communist allies or ideologically similar countries $[11,13]$. While choosing a host country with closer institutional quality can avoid barriers to entry and reduce the difficulty for MNEs to enter the market, it is not conducive to the long-term development of enterprises.

Institutional diversification provides opportunities for MNEs to exploit differences between two institutional environments. From the perspective of institutional arbitrage, by implementing the OFDI strategy in developed economies, Chinese MNEs can not only avoid the institutional constraints in the domestic market, but also be integrated into the advanced economies to obtain the strategic assets and use the comparative institutional advantages to induce institutional changes and improve the long-term competitiveness of enterprises. Xu and Shenkar [32] find that the MNEs with routine-based competitive advantages are more likely to enter markets that are normatively adjacent, whereas the MNEs with host country-based competitive advantages are more likely to enter markets with greater institutional distance. MNEs face large difficulties in the adaptation period, but once accepted by the host country, a barrier-like advantage and monopoly will be formed, so other similar enterprises will find it difficult to enter the host country. Driven by institutional arbitrage, SOEs will use overseas supervision vacancies and subsidies to accelerate overseas layout, which may cause excessive concentration of outward investment location. Based on the theory of institutional arbitrage, $\mathrm{Li}$ and $\mathrm{Hu}$ [33] believe that institutional constraints and lack of institutions during the institutional transition period are important reasons why China's OFDI is highly concentrated in tax havens. There are institutional arbitrage motivations when companies carry out OFDI activities, and institutional arbitrage and policy support have weakened the influence of conventional factors such as geographic distance, cultural distance, economic distance, and political risks on the OFDI location selection and geographical distribution of Chinese MNEs. Thus, we propose Hypothesis 1.

Hypothesis 1. Based on institutional arbitrage, formal institutional distance may have a positive impact on Chinese OFDI.

\subsection{The Impacts of the Informal Institutional Distance between} the Host Country and China on Chinese OFDI. The cultural differences between the home country and the host country determine the cultural barriers for MNEs to invest in the host country. When MNEs invest in the host country, they consider information flow, externality, information asymmetry, and adverse selection, among others. They also pay attention to the legitimacy of the market and thus obtain the recognition of suppliers, distributors, and consumers in the host country market, which is closely related to the cultural distance between the host country and the home country. If Chinese enterprises neglect local customs, cultural environment, labor rights, and interests, then it is hard for them to integrate into the local economic development environment in time and better realize the localized operation, leaving a bad impression on the host people, generating anti-Chinese sentiment, and disrupting the local investment and operation activities of enterprises. At the same time, the more Chinese people in the host country, the smaller the cultural difference between the host country and the home country, the lower the transaction cost of enterprises, and the easier it is to obtain a larger market share, which is more likely to drive the OFDI of overseas companies. In summary, we propose Hypothesis 2.

Hypothesis 2. The cultural distance between the host country and China is negatively related to Chinese OFDI.

\subsection{Asymmetric Effect of Institutional Distance on Chinese} OFDI. Aleksynska and Havrylchyk [27] find that when countries from the South invest in countries with better institutions, institutional distance can be viewed as a driving force; when emerging economies invest in countries with worse institutions, they are on average deterred by a large institutional distance, even though the effect is weaker in the case of South-South foreign direct investment. When investors seek natural resources and markets at the initial stage of OFDI, which are more likely to be found in poor institutional environment, a negative effect of an institutional distance can be outweighed by the appeal of natural resources and markets. Cultural distance may be asymmetric, which suggests the need to distinguish between home and host country specifics across institutional environments [34]. Generally, the institutional quality of developed countries is higher. Since developed countries believe that there is unfair competition in the state-owned enterprises and often restrict and hinder the investment of Chinese MNEs in sensitive industries such as high-tech and strategic energy on the grounds of national security, Chinese MNEs can only turn to countries with poor institutional quality. When Chinese investors seek assets like new technologies, brands, and intellectual property, which are more likely to be found in good institutional environment, they will choose the host country with closer institutions to avoid institutional barriers. In addition, Chinese MNEs tend to have a competitive advantage in countries with poor institutional quality, due to their experience in dealing with the complex institutional environment at home $[35,36]$. Thus, it is possible that the impact of institution environment and institutional distance on Chinese OFDI is different, depending on whether or not the institutional environment of the host country is better than that of China. Based on this, we propose Hypothesis 3.

Hypothesis 3. The role of institutional distance on Chinese OFDI is asymmetric. Depending on investment motivation and type of institution, Chinese OFDI may flow into host countries with a worse institution environment, or flow into host countries with a better institution environment. 


\section{Model and Variable Selection}

3.1. Variable Selection and Data Description. This paper uses the panel dataset of China's OFDI in 41 countries along the "Belt and Road" from 2003 to 2018. The countries along the "Belt and Road" are listed in Table 1.

3.1.1. Explained Variables. The explained variable is the volume of China's OFDI flows in the 41 countries along the "Belt and Road" and is expressed in the 2010 US constant price. The data is obtained from China Foreign Direct Investment Statistics Bulletin.

3.1.2. Explanatory Variables. The first explanatory variable is the informal institutional environment, which is the cultural distance between China and the host country (CD). It is measured by the six cultural dimensions given by Hofstede [37, 38]: power distance, individualism and collectivism, masculinity, uncertainty avoidance, long-term orientation, and laissez-funding and indulgence. The cultural distance is calculated as follows:

$$
\mathrm{CD}_{j t}=\frac{\sum_{1}^{6}\left(I_{i j}-I_{i c}\right)^{2} / V_{i}}{6}
$$

where $\mathrm{CD}_{j t}$ denotes the cultural distance between China and country $j$ in year $t ; I_{i j}$ and $I_{i c}$ denote, respectively, the $i$ th cultural dimension indicator values of country $j$ and China; and $V_{i}$ denotes the variance of the $i$ th cultural dimension. The data comes from the Hofstede personal database.

The second one is the political institutional environment (PI). This is measured by the six indicators given by the World Bank's Global Governance Indicators, including Discourse Rights and Responsibilities (VA), Political Stability and Non-Violence (PS), Government Efficiency (GE), Regulatory Quality (RQ), Rule of Law (RL), and Corruption Control (CC). We use the average of these six indicators to represent the overall score of political institutional environment, which ranges from -2.5 to 2.5 . The larger the value, the better the political institutional environment in the country. The data comes from the World Bank's Global Governance Indicators database. The calculation method of the political distance between China and the $j$ th country is as follows:

$$
\mathrm{PD}_{j t}=\frac{\sum_{1}^{6}\left(P_{i j}-P_{i c}\right)^{2} / P V_{i}}{6},
$$

where $\mathrm{PD}_{j t}$ denotes the political distance between China and country $j$ in year $t$ and $P_{i j}$ and $P_{i c}$ represent the values of the $i$ th political dimension of the $j$ th country and China, respectively. $\mathrm{PV}_{i}$ represents the variance of the $i$ th political dimension.

The third explanatory variable is the economic institutional environment (EI). This is measured by the economic freedom index released by the "Wall Street Journal" and the Heritage Foundation, which includes 5 dimensions: business freedom, monetary freedom, trade freedom, investment freedom, and financial freedom. The economic freedom
TABle 1: Countries along the "Belt and Road."

9 countries in ASEAN :

Indonesia, Malaysia, Philippines, Singapore, Thailand, Brunei,

Vietnam, Myanmar, Cambodia

1 country in East Asia: Mongolia

8 countries in West Asia:

Iraq, Turkey, Jordan, Israel, Saudi Arabia, UAE, Greece, Cyprus

5 countries in South Asia:

India, Pakistan, Bangladesh, Afghanistan, Nepal

7 countries in Commonwealth of Independent States (CIS):

Russia, Ukraine, Belarus, Georgia, Azerbaijan, Armenia, Moldova

11 countries in Central and Eastern Europe:

Poland, Lithuania, Estonia, Latvia, Czech Republic, Hungary,

Slovenia, Croatia, Serbia, Romania, Bulgaria

index is based on a percentage system (0-100). According to the score, each economy is listed in five different degrees of freedom, namely, "free economy" (score 80-100), "freer economy" (70 to below 80$)$, "medium free economy" (60 to less than 70), "less free economy" (50 to less than 60), and "pressed economy" (0 to less than 50 ). The higher the score, the higher the economic freedom. Economic distance is measured in the same way as political distance and cultural distance.

The above institutional distance measures solely the gap between the institutional environment of China and that of a host country and does not indicate whether the institution quality of the host country is better than China's institution quality. Therefore, we take the average value of subindicators of the cultural, political, and economic environment to represent the comprehensive score of the cultural, political, and economic environment. The direction of the institutional distance is represented by whether the difference between institutional scores is greater than zero. We use dummy variables to indicate the direction of the institutional distance, denoted by $P D D, E D D$, and $C D D$, respectively. A positive value of these dummy variables indicates a positive institutional distance; that is, the corresponding institutional environment of the host country is better than that of China. If these dummy variables are less than zero, then it indicates a negative institutional distance; that is, the corresponding institutional environment of the host country is poorer than that of China.

3.1.3. Control Variables. Anderson [39] uses the gravity model to analyze bilateral trade flows and concludes that bilateral trade between any two countries is proportional to their total economic output and inversely proportional to the distance between the two countries. Jiang and Jiang [40] analyze the location selection of China's OFDI based on the gravity model and find that China's OFDI has marketseeking, resources-seeking, and strategic-asset-seeking motivations and that institutional distance has a negative impact on China's OFDI. The investment gravity model contains the basic variables: China's total economic output (CGDP), total economic output of the host country (HGDP), and geographical distance (DIS) between China and the host country. China's total economic output is 
measured by China's real GDP and is expressed in 2010 US constant prices. China's GDP data comes from the China Statistical Yearbook. The total economic output of the host country is measured by real GDP of the host country, which is expressed in 2010 US constant prices. The data come from the United Nations account total database. Geographical distance (DIS) generally refers to the distance from the Chinese capital to the capital of the host country.

The motivations of China's outward foreign direct investment can be divided into market-seeking, strategic assetseeking, trade-seeking, and resource-seeking. In order to understand the investment motivation of China's OFDI, this paper also considers the following control variables: (1) market potential (HAGDP), measured by the real GDP per capital (constant price in 2010 U. S. dollars), (2) technological development level (RD), which is measured by the number of patent applications in the countries along the "Belt and Road", (3) degree of import dependence (EX), which is measured by the proportion of China's exports to the host country to the total imports of the host country, and (4) natural resource intensity (Nature), which is measured by the proportion of fuel, ore and metal exports in total exports. The above data comes from the WDI database.

The descriptive statistics of the major variables are reported in Table 2.

\subsection{Empirical Model}

3.2.1. Heckman Model with Trade Gravity. The gravity model is the main empirical research tool in the field of international trade. GDP levels proxy for OFDI demand, geographical, and institutional distance proxy for trade friction and coordination costs, and these proxies enable us to construct a gravity model. Thus, this paper mainly analyzes the influence of bilateral economic scale, geographical distance, cultural distance, political distance, and economic distance on China's outward foreign investment.

This paper uses China's outward foreign direct investments in 41 countries along the "Belt and Road" from 2003 to
2018 as a sample. We find that, in some years, China's investment in certain countries was zero, and even negative. One possible reason for this is that the changes in the institutional environment of the host country lead to changes in China's investment flows. Therefore, our sample is a selfselected sample rather than a random sample, meaning that there is a problem of sample selection bias. When some observations of sample are not exogenous and random, the estimated parameters will be biased. The Heckman model is to correct the estimation error caused by this bias [41, 42]. Therefore, this paper uses the Heckman two-stage model to examine the impact of factors such as bilateral institutional distance on China's outward foreign direct investment. Given the fact that there is a two-way causal relationship between China's OFDI and the host country's trade scale, as well as institutional distance, random perturbations can be related to explanatory variables. To address the endogenous problems, explanatory variables are lagged one period in the model.

The Heckman model allows for a two-stage decision process, in which MNEs first decide whether or not to outward invest (extensive margin) and then decide how much to invest (intensive margin). The Heckman model is in principle a suitable model if there is an exogenous variable that has a strong effect on the selection equation but has no effect on the level of OFDI (primary equation). In this paper, we use a Regional Trade Agreements dummy variable as the exogenous variable in the selection equation, but not in the primary equation. The signing of the agreements affects whether China makes the decision to outward invest in the host country, but it does not affect the level of outward foreign investment. China has signed Regional Trade Agreements (RTAs) with Mongolia, Turkey, Azerbaijan, Czech Republic, Georgia, Romania, Russia, Belarus, and Poland. For these countries, we set RTA $=1$, and RTA $=0$, if otherwise.

The Heckman model with trade gravity is as follows.

The first stage is the selection equation (the Probit model):

$$
\begin{aligned}
\operatorname{DOFDI}_{j t}= & \beta_{0}+\beta_{1} \ln \mathrm{CGDP}_{j(t-1)}+\beta_{2} \ln \mathrm{HGDP}_{j(t-1)}+\beta_{3} \ln \mathrm{DIS}_{j(t-1)} \\
& +\alpha_{1} \mathrm{CD}_{j(t-1)}+\alpha_{2} \mathrm{PD}_{j(t-1)}+\alpha_{3} \mathrm{ED}_{j(t-1)}+\lambda X_{j(t-1)}+r \mathrm{RTA}_{j(t-1)} .
\end{aligned}
$$

The second stage is the primary equation:

$$
\begin{aligned}
\ln \left(\mathrm{OFDI}_{j t}\right)= & \beta_{0}+\beta_{1} \ln \mathrm{CGDP}_{j(t-1)}+\beta_{2} \ln \mathrm{HGDP}_{j(t-1)}+\beta_{3} \ln \mathrm{DIS}_{j(t-1)} \\
& +\alpha_{1} \mathrm{CD}_{j(t-1)}+\alpha_{2} \mathrm{PD}_{j(t-1)}+\alpha_{3} \mathrm{ED}_{j(t-1)}+\lambda X_{j(t-1)}+\xi_{j t} .
\end{aligned}
$$

In equation (3), if OFDI ${ }_{j t}>0$, we set $\mathrm{DOFDI}_{j t}=1$, and if otherwise, DOFDI $_{j t}=0$; in equation (4), $\ln \left(\mathrm{OFDI}_{j t}\right) \mathrm{de}$ notes the logarithm of China's outward direct investment in country $j$ in year $t$; $\mathrm{CD}_{j(t-1)}$ is the cultural distance between
China and the host country in year $t-1 ; \mathrm{PI}_{j(t-1)}$ is the political institutional environment index of host country $j$ in year $t-1$; $\mathrm{Es}_{j(t-1)}$ is the economic institutional environment index of host country $j$ in year $t-1 ; \ln \operatorname{CGDP}_{j(t-1)}$ and 
TABLE 2: Variable definitions and descriptive statistics of variables.

\begin{tabular}{|c|c|c|c|c|c|c|}
\hline Variable & Meaning & Unit & Max & Min & Average & $\begin{array}{l}\text { Standard } \\
\text { deviation }\end{array}$ \\
\hline OFDI & China's foreign investment flows & U.S. $\$ 10,000$ & 1045248 & -45713 & 24891.31 & 74723.39 \\
\hline $\mathrm{CD}$ & Cultural distance & - & 7.72 & 0.55 & 2.88 & 1.82 \\
\hline $\mathrm{PD}$ & Political distance & - & 4.6 & 0.09 & 1.19 & 0.93 \\
\hline $\mathrm{ED}$ & Economic distance & - & 19.82 & 0.003 & 4.64 & 4.06 \\
\hline CGDP & China's GDP & U.S. $\$ 1,000,000,000$ & 94781.27 & 17989.83 & 50462.05 & 25475.03 \\
\hline HGDP & GDP of host country & U.S. $\$ 1,000,000,000$ & 59163.17 & 8.251781 & 5135.098 & 11929.82 \\
\hline DIS & Geographic distance & Kilometers & 7722.64 & 1172.05 & 5568.86 & 1754.18 \\
\hline HAGDP & Per capita GDP of host country & U.S. \$ & 60351.14 & 330.30 & 11112.38 & 12095.47 \\
\hline $\mathrm{RD}$ & $\mathrm{R} \& \mathrm{D}$ expenditure ( $\%$ of GDP) & $\%$ & 63.58 & 0 & 22.84 & 15.67 \\
\hline IM & Degree of dependence on import trade & $\%$ & 73.02 & 0.16 & 10.99 & 11.03 \\
\hline Nature & $\begin{array}{c}\text { Fuel, ore and metal exports (\% of merchandise } \\
\text { exports) }\end{array}$ & $\%$ & 99.79 & 0 & 24.42 & 27.29 \\
\hline
\end{tabular}

Note. In the table, the flow of China's foreign investment, China's GDP, GDP, and per capita GDP of the host country are all expressed in constant US dollars in 2010.

In $\mathrm{HGDP}_{j(t-1)}$, respectively, represent the economic scales of China and host country $j$ in year $t-1 ; \ln \operatorname{DIS}_{j(t-1)}$ is the geographical distance between China and host country $j . X$ denotes the control variables considered in the paper. $\eta_{j t}$ is the inverse Mills ratio. If the value of $\eta_{j t}$ is significant, then there is a sample self-selection problem, which means that the Heckman model is valid.

\section{Empirical Results}

4.1. Baseline Regression. The empirical results of the Heckman model are reported in Table 3. As can be seen from Table 3, inverse Mills ratio is not zero at the significance level of $10 \%$, meaning that the sample has self-selection deviation problem. This result justifies the need of adopting the Heckman model in the analysis.

As can be seen in Table 3, the estimated coefficients on China's GDP are significantly positive in both the first and second stages of Heckman model, indicating that China's economic scale plays a significant role in promoting the possibility of Chinese MNEs investing in the countries along the "Belt and Road" and the investment scale. The larger the scale of China's economy, the more it tends to invest in countries along the "Belt and Road," and the larger the scale of investment. The estimated coefficients on the economic scale of the host country is significantly positive in the first stage of Heckman, but not necessarily positive in the second stage, indicating that the larger the economic scale of the host country, the more it can attract the investment from Chinese MNEs. However, after Chinese MNEs enter the market of the host country, the local economic scale is not the main factor affecting the OFDI scale. The geographical distance between China and the host country has a significantly negative impact on the outward investment decisions and investment scale of Chinese NNEs, indicating that the longer the distance between China and the host country, the higher the transportation and transaction costs, leading to lower willingness of Chinese MNEs to invest in the host country and a lower level of investment. The signing of the Regional Trade Agreement (RTA) helps eliminate trade barriers between China and the host country and regulates the trade cooperation relationship. Therefore, RTA has a significant promotion effect on the outward investment decisions of Chinese MNEs. China is more inclined to invest in the host country signing RTA with China.

Focusing on the OFDI motivation, we note that the per capita GDP and the degree of import dependence of the host country have no significant impact on China's OFDI decisions and investment scale. The natural endowment of the host country has a significantly negative impact on China's OFDI decisions, but it has a significantly positive impact on China's outward investment scale. The technological level of the host country has a significantly negative impact on China's OFDI decisions and investment scale. Because most of the countries along the "Belt and Road" are developing countries, and the market competitiveness of Chinese MNEs in technologically developed countries is not extremely strong, Chinese MNEs tend to invest in countries with abundant resources and low technological levels. That is, China's investment in countries along the "Belt and Road" is not mainly driven by market-seeking, trade-seeking, or asset-seeking, but by resource-seeking.

The results in Table 3 also show that political distance has a significantly negative impact on China's foreign direct investment decisions, and a positive impact on China's foreign investment scale. The greater the political distance, the greater the differences between China and the host country in terms of regulatory quality, legal rules, and political corruption. This implies that Chinese MNEs are reluctant to invest in countries along the "Belt and Road", given the higher transaction costs and operating costs. However, once the Chinese MNEs enter the host country, the political distance is positively related to the scale of China's OFDI. This finding suggests that once China is willing to take the risk of political distance and invest in the host country, a higher investment scale can reduce transaction costs due to economies of scale, avoid the liability of foreignness, and even obtain gains through rent-seeking activities.

We further find that economic distance deters China's foreign direct investment decision, but it significantly promotes the scale of China's foreign investment. The greater the economic distance, the greater the difference in 


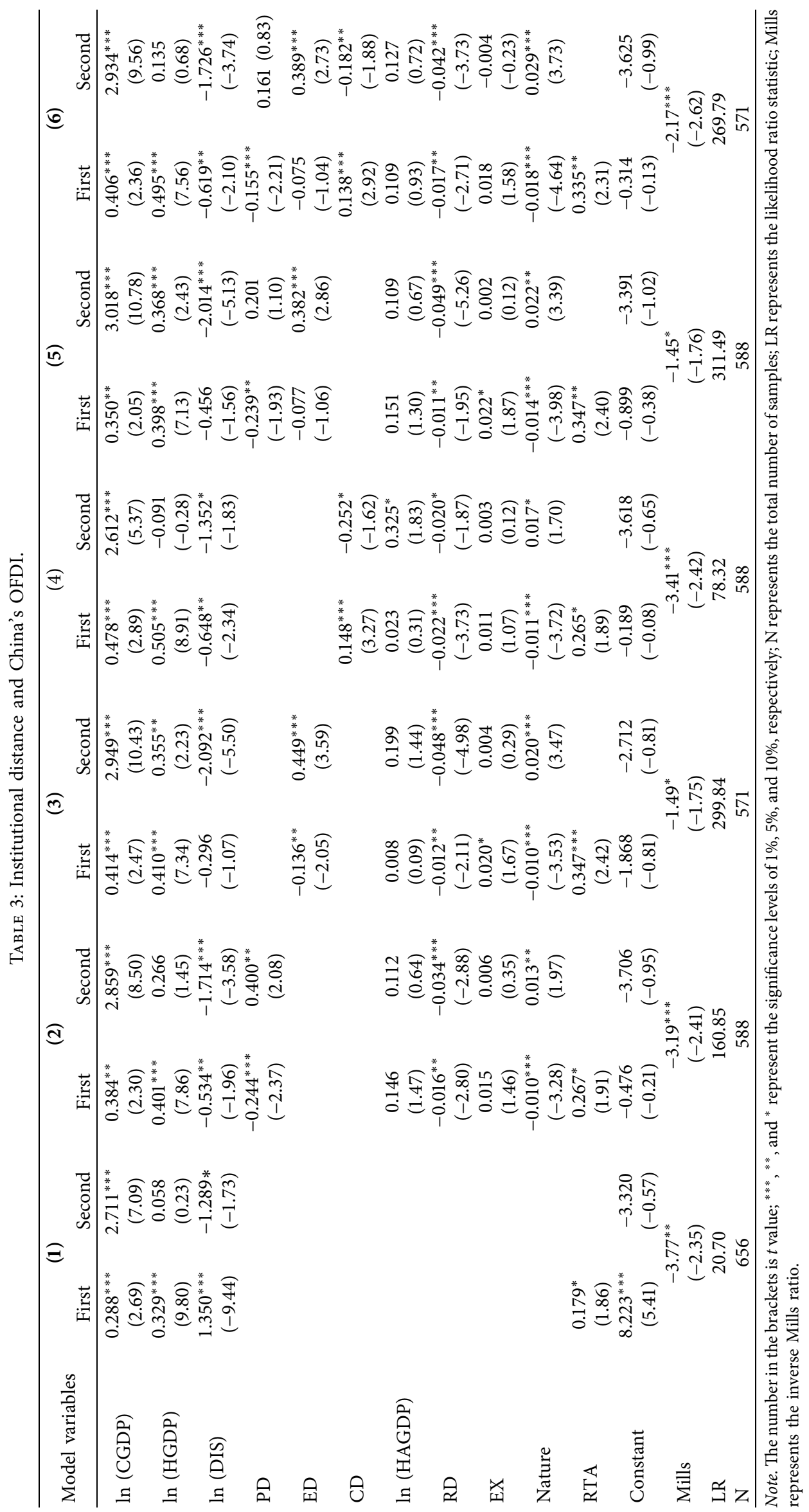


TABLE 4: Institutional preference.

\begin{tabular}{|c|c|c|c|c|c|c|}
\hline \multirow{2}{*}{ Model variables } & \multicolumn{2}{|c|}{ (1) } & \multicolumn{2}{|c|}{ (2) } & \multicolumn{2}{|c|}{ (3) } \\
\hline & First & Second & First & Second & First & Second \\
\hline $\ln (\mathrm{CGDP})$ & $\begin{array}{c}0.392^{* *} \\
(2.34)\end{array}$ & $\begin{array}{c}2.862^{* * *} \\
(9.56)\end{array}$ & $\begin{array}{c}0.543^{* *} \\
(2.24)\end{array}$ & $\begin{array}{c}3.166^{* * *} \\
(8.50)\end{array}$ & $\begin{array}{c}0.460^{* *} \\
(2.37)\end{array}$ & $\begin{array}{c}2.848^{* * *} \\
(6.84)\end{array}$ \\
\hline $\ln (\mathrm{HGDP})$ & $\begin{array}{c}0.41^{* * *} \\
(7.80)\end{array}$ & $\begin{array}{c}0.325^{* *} \\
(2.01)\end{array}$ & $\begin{array}{c}0.517^{* * *} \\
(7.46)\end{array}$ & $\begin{array}{c}0.476^{* * *} \\
(3.93)\end{array}$ & $\begin{array}{c}0.627^{* * *} \\
(8.93)\end{array}$ & $\begin{array}{c}0.157 \\
(0.54)\end{array}$ \\
\hline $\ln$ (DIS) & $\begin{array}{c}-0.473 * \\
(-1.68)\end{array}$ & $\begin{array}{c}-2.080^{* * * *} \\
(-4.77)\end{array}$ & $\begin{array}{l}0.257 \\
(0.68)\end{array}$ & $\begin{array}{c}-2.002^{* * *} \\
(-4.28)\end{array}$ & $\begin{array}{l}-0.567 \\
(-1.49)\end{array}$ & $\begin{array}{c}-1.771^{* * *} \\
(-2.61)\end{array}$ \\
\hline PD & $\begin{array}{c}-0.222^{* *} \\
(-2.10)\end{array}$ & $\begin{array}{c}0.302 * \\
(1.76)\end{array}$ & & & & \\
\hline PDD & $\begin{array}{l}0.189 \\
(0.92)\end{array}$ & $\begin{array}{c}-0.797^{* * *} \\
(-2.84)\end{array}$ & & & & \\
\hline $\mathrm{ED}$ & & & $\begin{array}{l}-0.066 \\
(-0.88)\end{array}$ & $\begin{array}{c}0.574^{* * *} \\
(3.94)\end{array}$ & & \\
\hline EDD & & & $\begin{array}{c}0.453^{* *} \\
(2.19)\end{array}$ & $\begin{array}{c}0.209 * \\
(1.77)\end{array}$ & & \\
\hline $\mathrm{CD}$ & & & & & $\begin{array}{c}0.198^{* * *} \\
(4.03)\end{array}$ & $\begin{array}{c}-0.307^{* *} \\
(-2.26)\end{array}$ \\
\hline CDD & & & & & $\begin{array}{l}0.015 \\
(0.64)\end{array}$ & $\begin{array}{l}0.011 \\
(0.30)\end{array}$ \\
\hline $\ln ($ HAGDP) & $\begin{array}{l}0.085 \\
(0.71)\end{array}$ & $\begin{array}{c}0.376^{* *} \\
(2.10)\end{array}$ & $\begin{array}{c}0.268^{* *} \\
(2.43)\end{array}$ & $\begin{array}{l}0.018 \\
(0.10)\end{array}$ & $\begin{array}{l}-0.039 \\
(-0.45)\end{array}$ & $\begin{array}{c}0.610^{* * *} \\
(3.74)\end{array}$ \\
\hline $\mathrm{RD}$ & $\begin{array}{c}-0.017^{* * *} \\
(-2.89)\end{array}$ & $\begin{array}{c}-0.034^{* * *} \\
(-3.25)\end{array}$ & $\begin{array}{c}-0.019^{* * *} \\
(-2.97)\end{array}$ & $\begin{array}{c}-0.049^{* * *} \\
(-4.73)\end{array}$ & $\begin{array}{c}-0.017^{* *} \\
(-2.58)\end{array}$ & $\begin{array}{c}-0.038^{* * *} \\
(-2.70)\end{array}$ \\
\hline EX & $\begin{array}{l}0.016 \\
(1.51)\end{array}$ & $\begin{array}{l}0.004 \\
(0.27)\end{array}$ & $\begin{array}{c}0.068^{* * *} \\
(3.42)\end{array}$ & $\begin{array}{l}0.009 \\
(0.37)\end{array}$ & $\begin{array}{l}0.006 \\
(0.32)\end{array}$ & $\begin{array}{l}0.006 \\
(0.17)\end{array}$ \\
\hline Nature & $\begin{array}{c}-0.009^{* * *} \\
(-2.78)\end{array}$ & $\begin{array}{l}0.007 \\
(1.24)\end{array}$ & $\begin{array}{c}-0.015^{* * *} \\
(-4.49)\end{array}$ & $\begin{array}{c}0.024^{* *} \\
(4.19)\end{array}$ & $\begin{array}{c}-0.013^{* * *} \\
(-4.07)\end{array}$ & $\begin{array}{c}0.027^{* * *} \\
(3.19)\end{array}$ \\
\hline RTA & $\begin{array}{c}0.295^{* *} \\
(2.05)\end{array}$ & & $\begin{array}{c}0.596^{* * *} \\
(3.38)\end{array}$ & & $\begin{array}{c}0.378^{* * *} \\
(2.53)\end{array}$ & \\
\hline Constant & $\begin{array}{l}-0.766 \\
(-0.33)\end{array}$ & $\begin{array}{l}-2.519 \\
(-0.71)\end{array}$ & $\begin{array}{c}-6.274^{* *} \\
(-2.09)\end{array}$ & $\begin{array}{l}-5.155 \\
(-1.34)\end{array}$ & $\begin{array}{l}-1.082 \\
(-0.40)\end{array}$ & $\begin{array}{l}-4.181 \\
(-0.89)\end{array}$ \\
\hline Mills & $\begin{array}{c}-1.951^{* *} \\
(-2.20)\end{array}$ & $\begin{array}{c}-0.933 * \\
(-1.65)\end{array}$ & $\begin{array}{c}-2.62^{* * *} \\
(-2.68)\end{array}$ & & & \\
\hline LR & 212.10 & 297.94 & 179.46 & & & \\
\hline $\mathrm{N}$ & 588 & 478 & 536 & & & \\
\hline
\end{tabular}

Note. The numbers in the brackets are $t$ values; ${ }^{* * *},{ }^{* *}$, and $*$ represent the significance levels of $1 \%, 5 \%$, and $10 \%$, respectively; $\mathrm{N}$ represents the total number of samples; LR represents the likelihood ratio statistic; and Mills represents the inverse Mills ratio.

the fiscal and trade environment between China and the host country, and the more obstacles Chinese MNEs face, resulting in lower willingness for Chinese MNEs to invest in the host country. But once Chinese MNEs enter the host country, they hope to reduce production costs, occupy a larger market share through larger investment scales, mitigate the risks brought by economic distance, and overcome the liability of foreignness. Collectively, large formal institutional distances, especially political distances, inhibit Chinese MNEs' willingness to invest in countries along the "Belt and Road," but once Chinese MNEs decide to invest in a country, larger institutional distances, especially economic distances, will promote Chinese MNEs reducing transaction costs and operating costs with a larger investment scale to reduce institutional risks. That is, formal institutional distance is positively related to China's OFDI scale.

Cultural distance has a significantly positive impact on China's foreign direct investment decisions, but it has a significantly negative impact on the scale of China's foreign investment. China is a typical eastern country. The cultural traditions of countries along the Belt and Road are extremely different from China. In order to achieve communication and dissemination between different cultures, China is more inclined to invest in other countries different from China in customs, religions, and habits. However, the large cultural differences make it difficult for Chinese MNEs to be recognized by local residents and hinder the further expansion of the investment in countries along the "Belt and Road." That is, China's foreign direct investment shows the characteristics of cultural distance proximity.

4.2. Institutional Preference. The previous empirical analysis does not consider whether the host country's institutional environment is better than that of China or worse than that of China. To examine the institutional preference of China's OFDI, we add to our regressions dummy variables that indicate the direction of the institutional distance. The estimation results are reported in Table 4. 
The estimation results of Model (1) show that the political quality of the host country has no significant impact on China's OFDI decisions, but it negatively impacts the scale of China's OFDI. This suggests that the scale of Chinese OFDI is relatively large in the host country with a political environment poorer than China. In addition, the market potential of the host country also has a significant appeal to the scale of China's OFDI. That is, China's OFDI exhibits the characteristics of political risk preference, and the main investment motivation is to expand the domestic market and open business to foreign markets.

The host country's economic environment has a significantly positive impact on China's OFDI decisions and has a positive impact on the scale of China's foreign investment, indicating that Chinese MNEs are more willing to invest in host countries with more economic freedom, and the scale of OFDI is directly proportional to the economic freedom of the host country. Moreover, China's OFDI is mainly driven by natural-resource-seeking.

The host country's cultural environment has a positive impact on China's foreign investment decision-making process and the scale of investment, but not statistically significant. This shows that Chinese MNEs are more willing to invest in a host country with a better cultural environment than that of China. However, the excessive cultural distance inhibits the expansion of China's OFDI. Therefore, Chinese MNEs invest in a host country with the similar cultural environment to China. Market-seeking and natural-resource-seeking are the main outward investment motivations.

\section{Conclusions}

Using the panel dataset of China's OFDI in 41 countries along the "Belt and Road" from 2003 to 2018, this paper investigates the impacts of the host country's institutional environment on China's OFDI, as well as the institutional risk preference of China's OFDI. To address the sampleselection bias and endogenous concerns, we adopt the twostage Heckman model with trade gravity in our analysis.

First, we find that large political distance reduces the willingness of Chinese MNEs to invest abroad, but once the investment decision is made, the amount of Chinese OFDI is positively correlated with political distance. In addition, economic institutional distance has a significantly positive impact on the amount of Chinese OFDI. Overall, the large formal institutional distance (political and economic institutional distance) complements, rather than replaces, the formal institution environment of China. Chinese OFDI shows the characteristics of formal institution paradox, and the amount of Chinese OFDI is motived by formal institutional arbitrage.

Second, cultural distance has a significantly negative impact on the amount of Chinese OFDI. Thus, formal institutional distance and informal institutional distance have different impacts on Chinese OFDI. The large potential cultural difference inhibits the further expansion of overseas investment, meaning that Chinese OFDI shows the characteristics of cultural distance proximity.
Third, we find that institutional distance has an asymmetric effect on Chinese OFDI. More specifically, the worse the host country's political environment, the larger the Chinese OFDI. That is, Chinese OFDI tends to flow into host countries with a worse political institutional environment. Chinese OFDI presents political institutional risk preference. On the contrary, the economic freedom of a host country has a positive impact on the level of Chinese OFDI. That is, Chinese OFDI tends to flow into host countries with a better economic institutional environment. Moreover, Chinese OFDI tends to flow into host countries with a better cultural institutional environment than China, but this effect is not statistically significant. Overall, Chinese OFDI tends to flow into host countries with a poorer political institutional environment, a better economic environment, and a similar cultural environment.

Our findings have important policy implications. First, it is important to establish an early warning system to reduce political risks. A considerable part of China's investment in the countries along the "Belt and Road" is concentrated in countries with high political risks, and the host country's political risk is an important factor affecting the risk and return of the investments of multinational enterprises. China should establish and improve the legal system and service system for OFDI and identify political risks in advance.

Second, it is also crucial to increase the operational autonomy of MNEs and create a relaxed economic environment. In particular, it is important to form a diversified development and flexible outward foreign investment pattern by establishing a new type of government-enterprise relationship that enables multinational corporations with conditions for foreign investment to enjoy foreign trade, financing and other financial management autonomy, simplifies foreign investment approval procedures, and encourages small- and medium-sized enterprises and private enterprises to invest abroad.

Third, it is also crucial to implement localized business strategies to encourage home country's enterprises to be rooted in host countries. In order to alleviate and eliminate cultural conflicts, the parent company improves the company's organizational structure and strengthens cross-cultural communication and management. On the other hand, it is recommended to appoint local senior management personnel in the host country's subsidiaries, follow local cultural traditions, establish production systems and business models that are adapted to the local operating environment, and reduce the operating and management costs of multinational enterprises.

Fourth, it is important to promote a proactive foreign policy and establish good bilateral relationships between the home country and the host country. In particular, it is helpful to actively establish partnerships with host countries, form sister cities, and sign cooperation documents that are conducive to protect investment and trade, such as the bilateral investment protection agreements and the agreement to avoid double taxation. Finally, the home country should reduce its dependence on fossil energy imports, develop strategic asset-seeking outward direct investment, 
strengthen the absorption of OFDI reverse technology spillovers, and help host countries improve infrastructure, expand employment, and promote economic growth to form an optimal allocation of global resources and a win-win situation for cooperation.

\section{Data Availability}

China's OFDI in the 41 countries along the "Belt and Road" is given by China Foreign Direct Investment Statistics Bulletin and is expressed in the 2010 US constant price. China's GDP data comes from the China Statistical Yearbook. The total economic output of the host country is measured by real GDP of the host country, which is expressed in 2010 US constant prices. The data come from the United Nations account total database. Geographical distance (DIS) generally refers to the distance from the Chinese capital to the capital of the host country. The economic institutional environment (EI) is measured by the economic freedom index released by the "Wall Street Journal" and the Heritage Foundation, which includes five dimensions: business freedom, monetary freedom, trade freedom, investment freedom, and financial freedom. The political institutional environment (PI) is measured by the six indicators given by World Bank's Global Governance Indicators. The cultural distance (CD) measured by the six cultural dimensions comes from the Hofstede personal database.

\section{Conflicts of Interest}

The authors declare that they have no conflicts of interest.

\section{Authors' Contributions}

Y. W. designed the model, conducted empirical research, and wrote the manuscript. G. P. collected data and verified the analytical methods. All authors discussed the results and contributed to the final manuscript. All authors have read and agreed to the published version of the manuscript.

\section{Acknowledgments}

This work was supported by the National Natural Science Foundations of China (71763010 and 71773041) and Young Academic Talents Project of Jiangxi University of Finance and Economics.

\section{References}

[1] B. Ramasamy, M. Yeung, and S. Laforet, “China's outward foreign direct investment: location choice and firm ownership," Journal of World Business, vol. 47, no. 1, pp. 17-25, 2012.

[2] G. Y. Yang, "The test of the predictability of China's stock market predictability," Financial Development, vol. 12, pp. 3-9, 2018.

[3] Q. G. Yuan and Y. S. Ji, "New changes in the political risks faced by Chinese enterprises OFDI and research trend," in Proceedings of the 4th International Social Sciences and Education Conference, Xiamen, China, March 2019.
[4] E. Asiedu, "On the determinants of foreign direct investment to developing countries: is Africa different?" World Development, vol. 30, pp. 107-119, 2002.

[5] M. Busse and C. Hefeker, "Political risk institutions and foreign direct investment," European Journal of Political Economy, vol. 23, pp. 397-415, 2007.

[6] M. Frenkel, K. Funke, and G. Stadtmann, "A panel analysis of bilateral FDI flows to emerging economies," Economic Systems, vol. 28, pp. 281-300, 2004.

[7] J. J. Li, "Global environmental competitiveness assessment method and robustness test," Philosophy and Social Sciences, vol. 5, pp. 36-41, 2014.

[8] S. J. Kobrin, "Political risk: a review and reconsideration," Journal of International Business, vol. 10, pp. 67-80, 1979.

[9] R. Lensink, N. Hermes, and V. Murinde, "Capital flight and political risk," Journal of International Money and Finance, vol. 19, pp. 73-92, 2000.

[10] G. H. Jiang and D. C. Jiang, "Is China's investment in developing countries important in the host country system?" Management World, vol. 11, pp. 45-56, 2012.

[11] P. J. Buckley, L. J. Clegg, and A. R. Cross, “The determinants of Chinese outward foreign direct investment," Journal of International Business Studies, vol. 38, pp. 499-518, 2007.

[12] Y. W. Cheung and X. Qian, "Empirics of China's outward direct investment," Pacific Economic Review, vol. 14, pp. 312-341, 2009.

[13] I. Kolstad and A. Wiig, "What determines Chinese outward FDI?" Journal of World Business, vol. 47, pp. 26-34, 2012.

[14] J. Liu, "Host country institutional environment investment orientation and OFDI research of Chinese multinational enterprises-_-analysis of Heckman model based on national data along the belt and road initiative," Foreign Economics and Management, vol. 4, pp. 56-68, 2018.

[15] K. E. Meyer, "Institutions transaction costs and entry mode choice in Eastern Europe," Journal of International Business Studies, vol. 32, pp. 357-367, 2001.

[16] M. Deng, "Institutional distance demonstration effect and the location distribution of China's OFDI," International Trade Issues, vol. 2, pp. 123-135, 2012.

[17] B. J. Wang, "The impact of economic system on China's foreign direct investment," Economic Management, vol. 1, pp. 110-119, 2019.

[18] J. Johanson and J.-E. Vahlne, "The Uppsala internationalization process model revisited: from liability of foreignness to liability of outsidership," Journal of International Business Studies, vol. 40, no. 9, pp. 1411-1431, 2009.

[19] M. Habib and L. Zurawicki, "Corruption and foreign direct investment," Journal of International Business Studies, vol. 33, pp. 291-307, 2002.

[20] Z. Pan, "Institutional quality institutional distance and bilateral trade," China Industrial Economy, vol. 7, pp. 46-52, 2006.

[21] B. X. Yue and T. Fan, "Institutional environment and China's location of direct investment in Asia," Finance Trade and Economics, vol. 6, pp. 70-78, 2014.

[22] C. L. Qi and C. Zou, "The quality of the host country system institutional distance and China's foreign direct investment location," Contemporary Finance and Economics, vol. 7, pp. 100-110, 2013.

[23] L. Guiso, P. Sapienza, and L. Zingales, "Cultural biases in economic exchange?*” Quarterly Journal of Economics, vol. 124, no. 3, pp. 1095-1131, 2009.

[24] K. Head and J. Ries, "FDI as an outcome of the market for corporate control: theory and evidence," Journal of International Economics, vol. 74, pp. 2-20, 2008. 
[25] E. Helpman, M. Melitz, and Y. Rubinstein, "Estimating trade flows: trading partners and trading volumes*," Quarterly Journal of Economics, vol. 123, no. 2, pp. 441-487, 2008.

[26] Y. M. Hu and X. Fan, "Bilateral investment agreement and location selection of China's foreign investment-- based on the perspective of institutional distance," China Price, vol. 6, pp. 18-25, 2017.

[27] M. Aleksynska and O. Havrylchyk, "FDI from the south: the role of institutional distance and natural resources," European Journal of Political Economy, vol. 29, pp. 38-53, 2013.

[28] J. Zhou, L. M. Zhang, and Y. Ge, "The influence of institutional environment on overseas investment of Chinese multinational enterprises: an analysis based on Heckman's two-phase selection model," International Business: Journal of University of International Business and Economics, vol. 1, pp. 104-113, 2015.

[29] D.C. North, Institutions Institutional Change and Economic Performance, Cambridge University Press, Cambridge, UK, 1990.

[30] A. Levchenko, "Institutional quality and international trade," Review of Economic Studies, vol. 74, pp. 791-819, 2007.

[31] Y. Algan and P. Cahuc, "Inherited trust and growth," American Economic Review, vol. 100, pp. 2060-2092, 2010.

[32] D. Xu and O. Shenkar, "Institutional distance and the multinational enterprise," The Academy of Management Review, vol. 274, pp. 608-618, 2002.

[33] N. Li and R. D. Hu, "Analysis on geographic distribution of Chinese outward foreign direct investment: a study from institution perspective," Economic Geography, vol. 31, pp. 910-914, 2011.

[34] O. Shenkar, "Cultural distance revisited: towards a more rigorous conceptualization and measurement of cultural differences," Journal of International Business Studies, vol. 32, no. 3, pp. 519-535, 2001.

[35] J. Child and S. B. Rodrigues, "The internationalization of Chinese firms: a case for theoretical extension?" Management and Organization Review, vol. 1, pp. 381-410, 2005.

[36] R. Morck, B. Yeung, and M. Zhao, "Perspectives on China's outward foreign direct investment," Journal of International Business Studies, vol. 39, pp. 337-350, 2008.

[37] G. Hofstede, "The business of international business is culture," International Business Review, vol. 3, pp. 1-14, 1994.

[38] G. Hofstede, "Dimensionalizing cultures: the Hofstede model in context," Online Readings in Psychology and Culture, vol. 2, pp. 1-26, 2011.

[39] J. E. Anderson, "A theoretical foundation for gravity equation," American Economic Review, vol. 69, pp. 106-116, 1979.

[40] G. H. Jiang and D. C. Jiang, "Location selection of China's foreign investment: panel data inspection based on investment gravity model," World Economy, vol. 9, pp. 21-40, 2012.

[41] J. J. Heckman, "Shadow price market wages and labor supply," Econometrica, vol. 42, pp. 679-694, 1974.

[42] J. J. Heckman, "Sample selection bias as a specification error," Econometrica, vol. 47, pp. 153-161, 1979. 